\title{
Petrogenesis of the Middle Triassic Yuanbaoshan leucogranite in southeast Inner Mongolia: Implication for the collision between Sino-Korean and Siberian paleoplates
}

\author{
SHUO ZHAO*, JIANFENG LIU, JIN ZHANG, JINYI LI,
} JUNFENG QU

Institute of Geology, Chinese Academy of Geological

Sciences, Beijing 100037, China (*correspondence:

zhaoshuo@cags.ac.cn)

The eastern Central Asian orogenic belt (CAOB) is situated between the Siberian craton to the north and the North China craton to the south. It is widely accepted that the eastern segment of the $\mathrm{CAOB}$, mainly in northern China, records the final closure of the Paleo-Asian Ocean (PAO), leading to terminal collision between Sino-Korean and Siberian paleoplates, which was along the Solonker-Xar Moron-Central Jilin suture. However, neither the timing of final closure of the PAO nor the style of subsequent collision between these two paleoplates have been satisfactorily and unanimously accepted. Here, we undertook new ages and geochemical and isotopic data for the Yuanbaoshan leucogranite in southeast Inner Mongolia, with the aim of discussing the process of these two paleoplates approaching each other to collide.

Zircons from representative samples are euhedral and subhedral in shape with typical oscillatory growth zoning in $\mathrm{CL}$ images, implying a magmatic origin. Zircon $\mathrm{U}-\mathrm{Pb}$ dating reveals that the leucogranite formed at $239 \pm 3 \mathrm{Ma}$, similar to the plateau age of $230.9 \pm 2.2$ Ma gived by muscovite ${ }^{40} \mathrm{Ar} /{ }^{39} \mathrm{Ar}$ dating, indicating that the leucogranite formed in late middle Triassic, not the early Permian as previously believed. The leucogranites, characterized by muscovite- and garnet-bearing, belong to peraluminous and high-K calcalkaline series, with compositions of $\mathrm{SiO}_{2}=74.45-76.16$ wt. $\%, \mathrm{Na}_{2} \mathrm{O}+\mathrm{K}_{2} \mathrm{O}=8.38-8.64$ wt. $\%$, and $\mathrm{A} / \mathrm{CNK}=1.04-$ 1.09. Together with enrichment in $\mathrm{K}$ and $\mathrm{Rb}$, depletion in $\mathrm{Ca}$, $\mathrm{Mg}, \mathrm{Ti}, \mathrm{Ba}, \mathrm{Sr}$ and REE, negative Eu anomalies $(\delta \mathrm{Eu}=0.27-$ $0.88)$ and $\varepsilon \mathrm{Nd}(\mathrm{t})$ values (-5.08 to -4.59$)$, and the tetrad effect of the REE distribution, we conclude that the leucogranite pluton is crust-derived, highly similar to those of Himalayan leucogranites undergone an intensive crystal fractionation. Combined with regional geological data, it is inferred that a largely destructive orogeny probably occured between SinoKorean and Siberian paleoplates lasted until the middle Triassic. This work is supported by NKRDPC (2017YFC0601301) and NSFC (41802068) 